\section{Gorontalo Hournal of Infrastructure \& Science Engineering}

\author{
Volume 2 - No. 2 - Oktober 2019 \\ P-ISSN: 2615-6962, E-ISSN: 2614-4638
}

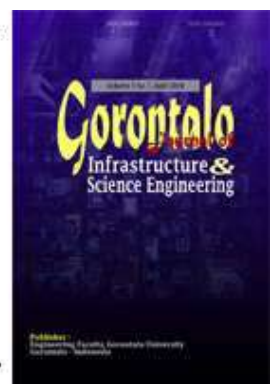

\title{
ANALISA PENGARUH KENAIKAN TEMPERATUR PERMUKAAN SOLAR CELL TERHADAP DAYA OUTPUT
}

\author{
Rifaldo Pido $^{a^{*},}$ Nurmala Shanti Dera ${ }^{\mathrm{b}}$, Mohamad Rival ${ }^{\mathrm{c}}$ \\ ${ }^{(a b c)}$ Teknik Mesin, Fakultas Teknik, Universitas Gorontalo \\ Jl. Abd wahab No. 225, Kabupaten Gorontalo \\ *E-mail: rifaldopido813@gmail.com
}

\begin{abstract}
This study discusses how the effect of rising solar panel temperatures on output power by comparison of water-cooled and non-refrigerated solar cells, cooling the solar cell by flowing water at the bottom of the panel. The power obtained by the solar cell can be determined by measuring the current and voltage with a multimeter. The test section is two specially designed solar cells with a capacity of 50 WP monocrystalline. The results obtained that the greater the increase in temperature of $50.92{ }^{\circ} \mathrm{C}$, the output power decreases for solar cells without water cooling 42.51 watts, while for solar cells with a flow of water power generated by 45.36 watts at surface temperature $34.36^{\circ} \mathrm{C}$, obtained at the same sun intensity.
\end{abstract}

Kata kunci: the solar cell; cooling water; temperature; output power

\begin{abstract}
Abstrak
Penelitian ini membahas bagaimana pengaruh kenaikan temperatur panel surya terhadap daya output dengan perbandingan solar cell berpendingin air dan tanpa pendingin, pendinginan pada solar cell dengan mengalirkan air pada bagian bawah panel. Besar daya yang diperoleh solar cell tersebut dapat diketahui dengan mengukur arus dan tegangan dengan multimeter. Seksi uji adalah dua buah sel surya dengan kapasitas 50 WP merk monocrystaline yang telah dirancang khusus. Hasil penelitian diperoleh bahwa semakin besar kenaikan temperatur $50,92^{\circ} \mathrm{C}$, maka daya output menurun untuk solar cell tanpa pendingin air 42,51 watt, sedangkan untuk solar cell dengan aliran air daya yang dibangkitkan sebesar 45,36 watt pada temperatur permukaan $34,36^{\circ} \mathrm{C}$, diperoleh pada intensitas matahari yang sama.
\end{abstract}

Kata kunci: solar cell; air pendingin; temperatur; daya keluaran

\section{PENDAHULUAN}

Konversi radiasi matahari menjadi energi listrik adalah cara yang paling efektif dalam pemanfaatan energi matahari. Keuntungan dari solar cell tersebut dapat menghasilkan energi listrik, tidak menimbulkan kebisingan dan polusi, usia pakai lama dan pemeliharaan yang rendah. Solar cell secara langsung mengubah radiasi matahari menjadi listrik dengan efisiensi puncak antara 9-12\%. Lebih dari $80 \%$ dari radiasi matahari tidak dikonversikan ke energi listrik, tetapi terpantulkan atau diubah menjadi energi panas. Hal ini menyebabkan kenaikan suhu kerja solar cell dan akibatnya menurunkan efisiensi konversi energi listrik (listrik yang murah).

Adhi warsito, dkk (2013) melakukan penelitian dengan membandingkan modul surya (solar cell) menggunakan kipas pendingin (heatsink fan), dan modul surya (solar cell) menggunakan heat sink tanpa kipas pendingin. Suhu maksimum Body pada panel surya berdasarkan spesifikasi berjenis SHARP ND 120T1D dengan batas kerja suhu sebesar $45^{\circ} \mathrm{C}$, jika suhu yang diperoleh melebihi dari $45{ }^{\circ} \mathrm{C}$ maka akan menurunkan keluaran dari panel surya sendiri. Pada penelitiannya didapatkan suhu rata-rata body panel surya pada pukul 09:00 pagi hingga 03:00 sore adalah $50.14^{\circ} \mathrm{C}$ dan keluaran rata-rata dari panel tersebut adalah 18.80 Volt. Sedangkan pada suhu rata-rata panel surya dengan penggunaan heatsink adalah $36^{\circ} \mathrm{C}$ dan keluaran rata-rata panel tersebut adalah 19.11 Volt. Dengan demikian maka dengan menggunakan pendingin heatsink penurunan 
rata-rata suhu sebesar $28.20 \%$ dan kenaikan keluaran dapat ditingkatkan sebesar $1.64 \%$ dari efisiensi panel surya ini yang hanya $12,1 \%$, [1]

Solar cell dapat bekerja secara optimum dengan kondisi tertentu. pengoperasian maksimum sel surya sangat tergantung pada temperatur panel surya, radiasi matahari, keadaan atmosfir bumi, orientasi panel surya, serta letak posisi panel surya (array) terhadap matahari (tilt angle). Banyak penelitian yang telah dilakukan tentang analisis faktor-faktor lingkungan yang mempengaruhi kinerja solar cell. D. Suryana dkk (2016) pada penelitianya menjelaskan bahwa tegangan listrik yang dihasilkan oleh suatu panel surya tidak hanya tergantung pada besarnya intensitas radiasi yang diterimanya, namun kenaikan temperature pada permukaan panel surya juga dapat menurunkan besar tegangan listrik tersebut, dimana pada bulan September dengan suhu sekitar $27^{\circ} \mathrm{C}$ tegangan yang dihasilkan 19,33Volt [2]. Perubahan temperatur pada panel surya selain disebabkan oleh temperature lingkungan sekitar, juga disebabkan oleh bahan silicon sel-sel surya yang mampu menyerap energi foton sekaligus panas dari radiasi matahari. Isyanto I, dkk, (2017) pada penelitianya mengenai peningkatan efisiensi modul surya dengan metode pendinginan menjelaskan bahwa Secara keseluruhan, ketika suhu mengalami penurunan, $\mathrm{V}_{\mathrm{OC}}, \mathrm{V}_{\mathrm{MP}}$ dan daya maksimum mengalami kenaikan. Seiring dengan kenaikan suhu sebesar $40^{\circ} \mathrm{C}, \mathrm{V}_{\mathrm{MP}}$ dan $\mathrm{V}_{\mathrm{OC}}$ masing-masing adalah $17.5 \mathrm{~V}$ dan $22 \mathrm{~V}$ dan daya maksimum adalah $10 \mathrm{~W}$, Ketika suhu turun ke $20 \mathrm{~V}$, VMP dan $\mathrm{V}_{\text {OC }}$ naik ke $20 \mathrm{~V}$ dan $24 \mathrm{~V}$ [3]

Tingginya suhu kerja solar cell dapat menurunkan daya out put, sehingga suhu kerja solar cell tidak dapat diturunkan dan akhirnya efisiensi konversi energi listrik dapat ditingkatkan. Untuk itu perlu dilakukan penelitian yang bertujuan untuk menghasilkan daya keluaran pada solar cell. Penelitian ini bertujuan untuk mengatahui pengaruh kenaikan temperatur panel surya terhadap daya output dengan perbandingan solar cell berpendingin air dan tanpa media pendingin. Besar daya yang diperoleh solar cell tersebut dapat diketahui dengan mengukur arus dan tegangan dengan multimeter.

\section{MATERIAL DAN METODE PENELITIAN}

Radiasi energi matahari merupakan sumber energi utama untuk proses-proses yang terjadi di Bumi. Energi matahari sangat membantu berbagai proses fisis dan biologis di Bumi. Radiasi adalah suatu proses perambatan energi (panas) dalam bentuk gelombang elektromagnetik yang tanpa memerlukan zat perantara. Energi Matahari bisa sampai ke permukaan Bumi adalah dengan cara radiasi (pancaran), karena diantara Bumi dan Matahari terdapat ruang hampa (tidak ada zat perantara), sedangkan gelombang elektromagnetik adalah suatu bentuk gelombang yang dirambatkan dalam bentuk komponen medan listrik dan medan magnet, sehingga dapat merambat dengan kecepatan yang sangat tinggi dan tanpa memerlukan zat atau medium perantara. Dari sekian banyak energi yang dikeluarkan matahari yang sampai ke Bumi melalui melalui proses perambatan panas kemudian diserap oleh Bumi.

2.1 Jenis-jenis solar cell antara lain:

1. Single crystalline

Yaitu kristal yang mempunyai satu jenis macamnya, tipe ini dalam perkembangannya mampu menghasilkan efisiensi yang sangat tinggi. Jenis single crystalline antara lain:

a. Gallium Arsenide Cell

Gallium arsenide cell sangat efisien dari semua sel, tetapi harganya sangat mahal. Efisiensi dari sel ini mampu mencapai 25 persen

b. Cadmium Sulfide Cell

Cadmium sulfide cell ini merupakan suatu bahan yang dapat dipertimbangkan dalam pembuatan sel surya, karena harga yang murah dan mudah dalam proses pembuatannya

2. Polycrystalline cell

Polycristalline cell merupakan kristal yang banyak macamnya, terbuat dari kristal silikon dengan efisiensi 10-12 persen.

3. Amorphous Silikon Cell

Amorphous berarti tidak memakai kristal struktur atau non kristal, bahan yang digunakan berupa proses film yang tipis dengan efisiensi sekitar 4-6 persen

4. Copper indium diselenide (CIS) cells

Bahan semikonduktor yang aktif dalam sel surya CIS adalah copper indium diselenide. Senyawa CIS sering juga merupakan paduan dengan gallium dan / atau belerang, [7]

Efisiensi 9 persen sampai 11 persen.

5. Cadmium telluride (CdTe) cells

Sel surya CdTe diproduksi pada substrat kaca dengan lapisan konduktor TCO transparan biasanya terbuat dari indium tin oxide (ITO) sebagai kontak depan. Efisiensi 1 persen hingga 8,5 persen per efisiensi modul.

6. Dye sensitized

Prinsip kerja Dye sensitized yaitu menyerap cahaya dalam pewarna organik mirip dengan cara di mana tanaman menggunakan klorofil untuk menangkap energi dari sinar matahari dengan fotosintesis.

2.2 Prinsip kerja sel surya 
Prinsip kerja sel surya silikon adalah berdasarkan konsep semikonduktor p-n junction. Sel terdiri dari lapisan semikonduktor doping-n dan doping-p yang membentuk p-n junction, lapisan antirefleksi, dan substrat logam sebagai tempat mengalirnya arus dari lapisan tipe-n (elektron dan tipe-p (hole).

Semikonduktor tipe-n didapat dengan mendoping silikon dengan unsur dari golongan $\mathrm{V}$ sehingga terdapat kelebihan elektron valensi dibanding atom sekitar. Pada sisi lain semikonduktor tipe-p didapat dengan doping oleh golongan III sehingga elektron valensinya defisit satu dibanding atom sekitar. Ketika dua tipe material tersebut mengalami kontak maka kelebihan elektron dari tipe-n berdifusi pada tipe-p. Sehingga area doping-n akan bermuatan positif sedangkan area doping-p akan bermuatan negatif. Medan elektrik yang terjadi pada keduanya mendorong elektron kembali ke daerah-n dan hole ke daerah-p. Pada proses ini telah terbentuk p-n junction. Dengan menambahkan kontak logam pada area $\mathrm{p}$ dan $\mathrm{n}$ maka telah terbentuk dioda. Cara kerja sel surya dapat dilihat pada Gambar 1 dibawah ini.

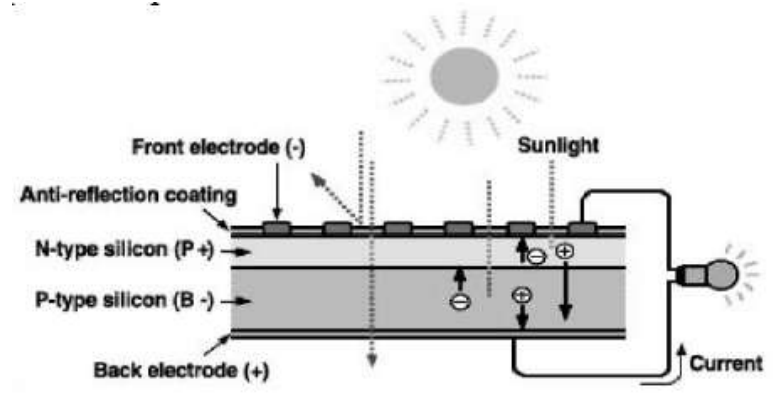

Gambar 1. Cara kerja sel surya silikon, [4]

2.3 Arus hubung singkat (Short circuit current, $I_{s c}$ )

Arus hubung singkat (Short circuit current, $I_{s c}$ ) adalah arus yang melalui sel surya saat tegangan pada sel surya sama dengan nol, I=0 (yaitu, ketika sel surya mengalami hubungan arus pendek).

2.4 Rangkaian tegangan terbuka (open circuit voltage)

Rangkaian tegangan terbuka (open circuit voltage) adalah tegangan maksimum dari sel surya dan ini terjadi pada saat arus sel sama dengan nol $(\mathrm{I}=0)$.

2.5 Parameter pada kurva arus (I) dan tegangan $(V)$

Satwiko S dkk, (2011) dalam penelitiannya mengemukakan bahwa karakteristik arus dan tegangan sel surya dapat berubah apabila besaran intensitas cahaya matahari mengenai permukaan panel surya juga berubah, maka semakin besar pula dan daya dan efisiensi yang dihasilkan. Untuk mengetahui karakteristik arus dan tegangan pada sel surya dengan kondisi beban atau resistensi yang berbeda beda, dapat diperlihatkan pada Gambar 2 Kurva karakteristik arus dan tegangan I-V dibawah ini [4].

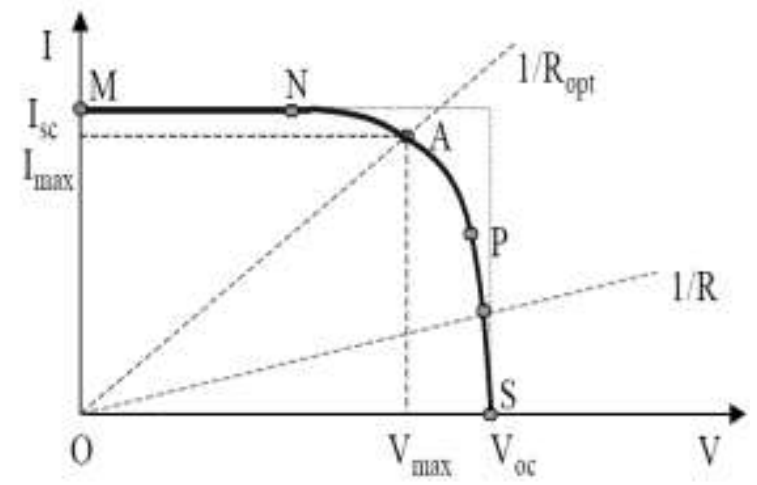

Gambar 2. Kurva karakteristik arus dan tegangan I-V, [5]

Hansen, dkk, (2001), menjelaskan parameter untuk menentukan nilai output pada sel surya meliputi:

a. Arus hubung singkat atau short circuit current $\left(\mathrm{I}_{\mathrm{sc}}\right)$ adalah arus keluaran maksimum yang di peroleh dari sel surya pada kondisi tidak ada resistansi $(\mathrm{R}), \mathrm{V}=0$.

b. Tegangan hubung terbuka atau open circuit voltage $\left(\mathrm{V}_{\mathrm{oc}}\right)$ adalah kapasitas tegangan maksimum yang dapat dicapai pada saat tidak adanya arus.

c. Daya maksimum $\left(\mathrm{P}_{\max }\right)$ pada Gambar 1 , berada pada titik $\mathrm{A}\left(\mathrm{V}_{\max }, \mathrm{I}_{\max }\right)$.

d. Faktor pengisian atau Fill Factor (FF) merupakan harga yang mendekati konstanta suatu sel surya tertentu. Jika nilai FF lebih tinggi dari 0.7, maka sel surya tersebut lebih baik. 


\subsection{Faktor pengisi}

Faktor pengisi adalah ukuran kualitas dari sel surya dapat diketahui dengan membandingkan daya maksimum teoritis dan daya output pada tegangan rangkaian terbuka dan hubungan pendek. Faktor pengisi yaitu parameter yang menyatakan seberapa besar $I_{s c} \times V_{o c}$ dari daya maksimum $V_{m} \times I_{m}$ yang dihasilkan sel surya [6]

$$
F F=\frac{V_{m} \times I_{m}}{V_{o c} I_{s c}}
$$

Dengan:

$\mathrm{FF}=$ Faktor pengisi

$\mathrm{V}_{\mathrm{m}}=$ Tegangan maksimum $(\mathrm{V})$

$\mathrm{I}_{\mathrm{m}} \quad=$ Arus maksimum (A)

$\mathrm{V}_{\mathrm{oc}}=$ Rangkaian tegangan terbuka $(\mathrm{V})$

$\mathrm{I}_{\mathrm{sc}} \quad=$ Arus hubung singkat $(\mathrm{A})$

\subsection{Daya}

Daya adalah besaran yang diturunkan dari nilai tegangan dan arus sehingga sehingga nilai tegangan dan arusyang dihasilkan merupakan bagian dari kelistrikan yang dimiliki oleh sel surya. [6]

Dengan :

$$
\begin{aligned}
\mathrm{P} & =\operatorname{Daya}(\mathrm{W}) \\
\mathrm{V} & =\operatorname{Tegangan}(\mathrm{V}) \\
\mathrm{I} & =\operatorname{Arus}(\mathrm{A})
\end{aligned}
$$

$$
P=V . I
$$

\subsection{Daya maksimum}

Daya maksimum $\left(\mathrm{P}_{\mathrm{m}}\right)$ diperoleh dengan arus dan tegangan pada setiap titik A kurva $I-V$ pada Gambar 1 . Secara grafis daya maksimum pada sel surya berada pada puncak yang memiliki luas terbesar. Titik puncak tersebut dapat disebut maximum power point (MPP). [6]

Daya maksimum dari sel surya dapat dihitung dengan Persamaan (3):

\section{Dengan :}

$$
P_{m}=V_{m} \cdot I_{m}
$$

$\mathrm{P}_{\mathrm{m}} \quad=$ Daya maksimum keluaran $(\mathrm{W})$

$\mathrm{V}_{\mathrm{m}}=$ Tegangan maksimum $(\mathrm{V})$

$\mathrm{I}_{\mathrm{m}} \quad=\operatorname{Arus}$ maksimum $(\mathrm{A})$

\subsection{Daya masuk}

Sukhatme dkk, ( 2008), Daya masuk $\left(\mathrm{P}_{\text {in }}\right)$ diperoleh dari perkalian antara intensitas radiasi matahari yang diterima dengan luas area solar cell dapat dihitung dengan persamaan (4) [6]

$$
\mathrm{P}_{\text {in }}=\operatorname{Ir} \times \mathrm{A}
$$

$P_{\text {in }}=$ Daya input akibat radiasi matahari $(\mathrm{W})$

Ir = Intensitas radiasi matahari $\left(\mathrm{W} / \mathrm{m}^{2}\right)$

A $=$ Luas area permukaan sel surya $\left(\mathrm{m}^{2}\right)$

\subsection{Daya keluaran}

Sukhatme dkk ( 2008), Daya keluaran $\left(\mathrm{P}_{\text {out }}\right)$ pada sel surya yaitu besaran nilai dari hasil perkalian antara tegangan rangkaian terbuka $\left(\mathrm{V}_{\mathrm{oc}}\right)$. dengan arus hubung singkat $\left(\mathrm{I}_{\mathrm{sc}}\right)$ dan faktor pengisi (FF) yang dihasilkan oleh sel surya dapat dihitung dengan persamaan (5) [6]

$$
\mathrm{P}_{\text {out }}=\operatorname{Voc} \times \text { Isc } \times \text { FF. }
$$

\section{Dengan:}

$\mathrm{P}_{\text {out }}=$ Daya keluaran $(\mathrm{W})$

$\mathrm{V}_{\mathrm{oc}}=$ Tegangan rangkaian terbuka $(\mathrm{V})$

$\mathrm{I}_{\mathrm{sc}} \quad=$ Arus hubung singkat $(A)$

$F F=$ Faktor pengisi 


\section{HASIL DAN PEMBAHASAN}

Penelitian ini merupakan salah satu langkah untuk mengetahui bagaimana pengaruh kenaikan temperatur panel surya terhadap daya output dengan perbandingan solar cell berpendingin air dan tanpa pendingin.

\subsection{Pengaruh Temperatur permukaan Solar Sell Terhadap Daya Output Menggunakan Media Air Pendingin}

Presentase hasil perhitungan antara arus dan tegangan berdasarkan persamaan (1) dapat dilihat pada Tabel 1, pada penelitian ini diperoleh daya mulai dari waktu pengukuran pada pukul 08:00 WITA sampai dengan pukul 16:00 WITA, penggunaan media air sebagai fluida kerja dengan cara dialirkan pada bagian bawah sel surya dapat mempengaruhi daya listrik

Tabel 1. Hasil perhitungan daya listrik dengan aliran air terhadap temperatur permukaan solar cell

\begin{tabular}{cccc} 
No & Waktu (jam) & Daya P $($ Watt) & Temperatur Atas $\left({ }^{\circ} \mathbf{C}\right)$ \\
\hline 1 & 08.00 & 10,78 & 30,32 \\
2 & 09.00 & 32,54 & 34,18 \\
3 & 10.00 & 41,39 & 33,39 \\
4 & 11.00 & 44,94 & 33,94 \\
5 & 12.00 & 45,36 & 34,36 \\
6 & 13.00 & 44,94 & 34,18 \\
7 & 14.00 & 41,80 & 33,89 \\
8 & 15.00 & 33,62 & 32,98 \\
9 & 16.00 & 20,39 & 33,12 \\
\hline
\end{tabular}

Pengaruh temperatur permukaan solar cell dapat dilihat pada gambar 3, terlihat bahwa daya keluaran yang dihasilkan pada pukul 08:00 WITA sebesar 10,78 Watt pada temperatur $30,32^{\circ} \mathrm{C}$, seiring dengan peningkatan intensitas cahaya matahari pada pukul 12:00 WITA daya listrik diperoleh sebesar 45,36 Watt pada temperatur $34,36^{\circ} \mathrm{C}$, seiring dengan penurunan intensitas cahaya matahari pada pukul 16:00 WITA temperatur panel mengalami pelemahan yaitu sebesar $33,12{ }^{\circ} \mathrm{C}$ begitupun daya yang dihasilkan akan mengalami pelemahan sebesar 20,39 Watt, hal ini sesuai dengan hasil penelitian yang dilakukan oleh Hasbi dkk (2019), tentang analisis pengaruh perubahan temperatur panel terhadap daya dan efisiensi keluaran sel surya, hasil penelitiannya menunjukkan bahwa pada pukul 08.00 WITA daya yang diperoleh sebesar 7,360 Watt dengan efisien tertinggi yaitu 9,66\% sedangkan pada pukul 12.00WITA daya keluaran yang di perolah sebesar 17.03 Watt dengan efisien tertinggi $9,44 \%$. Perubahan temperatur pada permukaan panel surya dapat memepengaruhi unjuk kerja system solar cell yang berdampak pada daya keluaran dan efisiensi kerja [8].

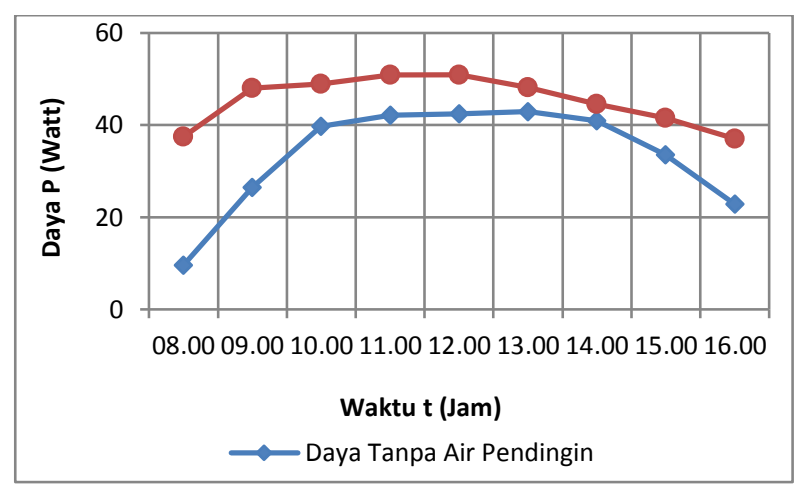

Gambar 3. Grafik perhitungan daya dengan aliran air terhadap temperatur permukaan solar cell

\subsection{Pengaruh Temperatur permukaan Solar Sell Terhadap Daya Output Tanpa Menggunakan Media Air Pendingin}

Pengaruh Temperatur permukaan Solar Sell tanpa menggunakan media air pendingin menghasilkan daya listrik yang lebih kecil dan temperatur permukaan atas lebih besar dibandingkan dengan solar cell berpendingin, seperti yang diperlihatkan pada tabel 2 dan Gambar 4, daya listrik yang dihasilkan pada pukul 08:00 WITA 9,58 Watt pada temperatur $37,40{ }^{\circ} \mathrm{C}$, seiring dengan peningkatan intensitas cahaya matahari daya listrik yang dibangkitkan pada pukul 12:00 WITA sebesar 42,51 Watt pada temperatur $50,92{ }^{\circ} \mathrm{C}$, seiring dengan penurunan intensitas cahaya matahari pada pukul 16:00 WITA temperatur panel mengalami pelemahan yaitu sebesar $37,06{ }^{\circ} \mathrm{C}$ begitupun daya yang dihasilkan akan mengalami pelemahan sebesar 22,80 Watt. Arifandi dkk 
(2017) telah melakukan penelitian dengan menggunakan dua buah panel, untuk sel surya tanpa mengunakan air pendingin daya yang dihasilkan sebesar 13,61 Watt [9]

Tabel 2. Hasil perhitungan daya tanpa aliran air terhadap temperatur permukaan solar cell

\begin{tabular}{cccc}
\hline No & Waktu (jam) & Daya P (Watt) & Temperatur Atas $\left({ }^{\circ} \mathbf{C}\right)$ \\
\hline 1 & 08.00 & 9,58 & 37,40 \\
2 & 09.00 & 26,50 & 47,99 \\
3 & 10.00 & 39,78 & 48,95 \\
4 & 11.00 & 42,12 & 50,88 \\
5 & 12.00 & 42,51 & 50,92 \\
6 & 13.00 & 42,94 & 48,18 \\
7 & 14.00 & 40,98 & 44,51 \\
8 & 15.00 & 33,49 & 41,58 \\
9 & 16.00 & 22,80 & 37,06 \\
\hline
\end{tabular}

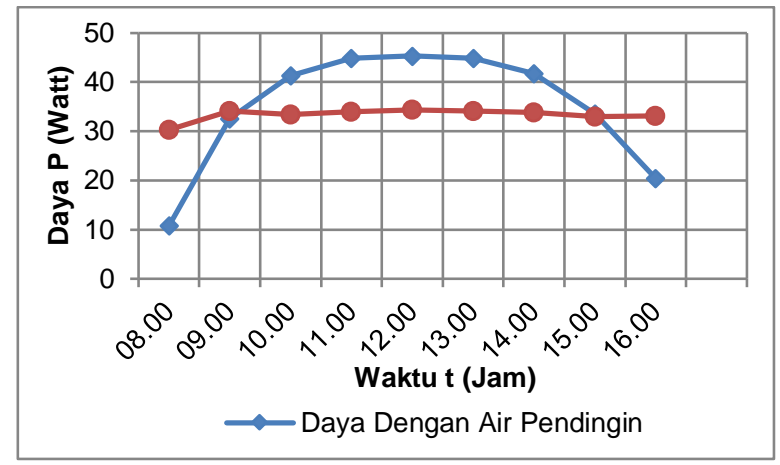

Gambar 4. Grafik perhitungan daya tanpa aliran air terhadap temperatur permukaan solar cell

\section{KESIMPULAN}

Hasil analisa dan pembahasan dapat disimpulkan bahwa Peningkatan efisiensi sel surya dengan metode pendinginan menggunakan air sebagai fluida kerja dapat meningkatkan daya dan efisiensi. Kesimpulan hasil eksperimen menunjukan bahwa :

a) Kenaikan temperatur permukaan sel surya menyebabkan sistem kerja solar cell terganggu. metode pendinginan dengan cara mengalirkan air pada bagian belakang sel surya berhasil menurunkan temperatur dari $50,92{ }^{\circ} \mathrm{C}$ menjadi $34,36{ }^{\circ} \mathrm{C}$ sedangkan daya keluaran

b) Pada sel surya berpendingin dengan debit air sebesar $150 \mathrm{ml} / \mathrm{s}$ daya diperoleh 45,36 $\mathrm{W}$ dan efisiensi yang didapatkan sebesar $10,07 \%$, Sedangkan untuk sel surya tanpa pendingin daya maksimum diperoleh sebesar 42,51 W, dan efisiensi yang diperoleh 9,44\%.

c) Pengukuran intensitas cahaya matahari, temperatur, arus dan tegangan sebaiknya menggunakan Data logger untuk meminimalisir kesalahan pengukuran. Perlu dilakukan pengukuran temperatur lingkungan dan kecepatan angin sebagai acuan perbandingan.

\section{DAFTAR PUSTAKA}

[1] Adhi warsito, erwin adriono, m.yudi nugroho, oding, and bambang winardi. 2013., Dipo pv cooler, penggunaan sistem pendingin temperatur Heatsink fan pada panel sel surya (photovoltaic) sebagai Peniingkatan kerja energi listrik baru terbarukan, jurnal Transient, vol. 2, No. 3, issn: 2302-9927, 500

[2] Deny suryana dan M. Marhaendra ali, 2016., Pengaruh temperatur/suhuterhadap tegangan yang dihasilkan panel surya jenis monokristalin., (Studi kasus: baristand industri surabaya), Jurnal teknologi proses dan inovasi industri, vol. 2, no. 1, Kementerian perindustrian baristand industri surabaya, indonesia

[3] Haris isyanto, Budiyanto, Fadliondi, Prian Gagani, 2017., Pendingin untuk peningkatan daya keluaran panel surya, Jurusan Teknik Elektro, Fakultas Teknik, Universitas Muhammadiyah Jakarta, Seminar Nasional Sains Dan Teknologi

[4] Satwiko Sidopekso, Hadi Nasbey, Arymukti Wibowo, 2011, Pengukuran I-V dengan Menggunakan Sun Simulator Sederhana, Jurnal ilmiah elite elektro, Vol. 2, No. 2, :79-82

[5] Hansen, A.D, Sorensen, P.E, Hansen, L.H, Bindner, H.W, 2001, "Models for a stand-alone PV system.” Roskilde : Riso National Laboratory, Techinal University Of Denmark. 
[6] Sukhatme, J K Nayak, 2008, "Solar Energy principles of thermal collection and storye”, Book, New Delhi.

[7] Planning And Installing Photovoltaic System. 2008. Book, Earthscan. London

[8] Hasbi Assiddiq dan Mochamad Bastomi, (2019)., Analisis pengaruh perubahan temperatur panel terhadap daya dan efisiensi keluaran sel surya poycrystalline. Jurusan Teknik Mesin , Politeknik Kotabaru.

[9] Afriandi, Ismail Yusuf, Ayong Hiendro, (2017)., Implementasi Water Cooling System Untuk Menurunkan Temperature Losses Pada Panel Surya , Program Studi Teknik Elektro Jurusan Elektro Fakultas Teknik Universitas Tanjungpura Pontianak 